\title{
SCALE DEPENDENCE OF OAK WOODLAND HISTORICAL FIRE INTERVALS: CONTRASTING THE BARRENS OF TENNESSEE AND CROSS TIMBERS OF OKLAHOMA, USA
}

\author{
Michael C. Stambaugh ${ }^{1^{*}}$, Richard P. Guyette ${ }^{1}$, Joseph M. Marschall ${ }^{1}$, and Daniel C. Dey ${ }^{2}$ \\ ${ }^{1}$ Department of Forestry, University of Missouri, \\ 203 ABNR Building, Columbia, Missouri 65211, USA \\ ${ }^{2}$ USDA Forest Service, Northern Research Station, University of Missouri, \\ 202 ABNR Building, Columbia, Missouri 65211, USA
}

*Corresponding author: Tel.: +1-573-882-8841; e-mail: stambaughm@missouri.edu

RESUMEN

\begin{abstract}
Characterization of scale dependence of fire intervals could inform interpretations of fire history and improve fire prescriptions that aim to mimic historical fire regime conditions. We quantified the temporal variability in fire regimes and described the spatial dependence of fire intervals through the analysis of multi-century fire scar records ( 8 study sites, 332 trees, 843 fire scars) derived from two historically post oak (Quercus stellata Wangenh.) woodland landscapes. Despite large differences in fire environment conditions, study sites $\left(\sim 1 \mathrm{~km}^{2}\right)$ burned frequently (mean fire interval $[\mathrm{MFI}] \leq 10$ yr) before Euro-American settlement (pre-EAS), with sites in Tennessee showing higher overall fire frequency than sites in Oklahoma, USA. PreEAS MFIs decreased exponentially with increasing spatial extent from individual trees $\left(\sim 1 \mathrm{~m}^{2}\right)$ to landscapes $\left(\sim 100 \mathrm{~km}^{2}\right)$. The relationship between MFI and spatial extent may help to explain how historical observations of annual burning could be recorded in woodlands, when experimental studies suggest that this is too frequent for
\end{abstract}

La caracterización de la dependencia de la escala de los intervalos de fuego podría informar sobre interpretaciones de la historia del fuego y mejorar prescripciones que apunten a imitar condiciones históricas del régimen de incendios. Nosotros cuantificamos la variabilidad temporal en los regímenes de fuego y describimos la dependencia espacial de intervalos de fuego a través del análisis de archivos de cicatrices de fuego por muchas centurias ( 8 sitios de estudio, 332 árboles, 843 cicatrices de fuego) derivados de dos paisajes históricos de arbustales de roble de los postes (Quercus stellata Wangenh). A pesar de las grandes diferencias en las condiciones ambientales de fuego, los sitios de estudio $\left(\sim 1 \mathrm{~km}^{2}\right)$ se quemaron frecuentemente (intervalo promedio de fuego $[\mathrm{MFI}] \leq 10$ años) antes del asentamiento euro-americano (pre-EAS), mostrando una frecuencia general de fuegos en los sitios de Tennessee más alta que en los de Oklahoma, EEUU. Los MFIs en el pre-EAS decreció en forma exponencial con el grado de aumento espacial desde árboles individuales $\left(\sim 1 \mathrm{~m}^{2}\right)$ hasta paisajes $\left(\sim 100 \mathrm{~km}^{2}\right)$. La relación entre en MFI y la extensión espacial puede ayudar a explicar como observaciones históricas de quemas anuales podrían ser recopiladas en arbustales, cuando estudios experimentales sugieren que 
tree recruitment. Further investigations of spatial dependence of fire intervals would improve our ability to relate historical and experimental fire data to present day fire prescriptions, and vice versa. esto es muy frecuente para el reclutamiento de árboles. Otras investigaciones de la dependencia espacial de los intervalos de fuego podrían mejorar nuestra habilidad para relacionar datos históricos y experimentales de fuego a prescripciones actuales de fuego y vice versa.

Keywords: management, oak woodland, pyrodiversity, restoration, spatial extent, succession

Citation: Stambaugh, M.C., R.P. Guyette, J.M. Marschall, and D.C. Dey. 2016. Scale dependence of oak woodland historical fire intervals: contrasting The Barrens of Tennessee and Cross Timbers of Oklahoma, USA. Fire Ecology 12(2): 65-84. doi: 10.4996/fireecology.1202065

\section{INTRODUCTION}

Nineteenth- to twentieth-century trends of oak (Quercus spp. L.) woodland communities in the eastern US overwhelmingly show transition to more closed-canopy conditions and fire-intolerant tree species (Dyer 2001, Nowacki and Abrams 2008, Hanberry et al. 2014). Prior to Euro-American settlement (pre-EAS) and logging effects, fire was considered the primary disturbance that maintained oak woodland communities. Interest in woodland restoration and management is increasing, not only because of historical prevalence and modern rarity, but also due to the multiple ecological benefits resulting from fire restoration compared to fire suppression. Recently, research has focused on how fire treatments may be incorporated into silvicultural systems (Ryan et al. 2013, Brose 2014, Dey and Kabrick 2015). Detailed and spatially explicit information is needed about the fire ecology of woodlands, including how species and ecosystem function respond to specific fire regime conditions, and how or if tree recruitment can be sustained through repeated, long-term burning. Specifically, understanding the scale dependencies of fire intervals would improve the ability to crosswalk between sources that characterize woodlands such as historical data, experimental data, and present day fire monitoring. Additionally, quantifying the variability in fire intervals across spatial and temporal scales may in- form us about their relative importance as related to oak woodland development.

Oak woodlands are highly variable forest communities with open canopies ranging from $30 \%$ to $100 \%$ closure; sparse midstories; and a dense ground flora rich in forbs, grasses, and sedges (Nelson 2005). Historically, woodlands existed in ecoregions throughout the Eastern deciduous forest (Braun 1950, Bailey 1997), including being embedded components of glades, barrens, and oak-pine ecosystems, accompanying shortleaf pine (Pinus echinata Mill.), longleaf pine (P. palustris Mill.), red pine ( $P$. resinosa Aiton), and pitch pine ( $P$. rigida Mill.). Mature canopy heights may range from $6 \mathrm{~m}$ to $27 \mathrm{~m}$ depending on site conditions. Nelson (2005) identified 18 different oak woodland communities in Missouri, USA, and vascular plant species richness can exceed 200 species ha-1. Diverse species compositions and open canopy structures of woodlands are attributed to repeated and relatively frequent fires (Olmstead 1857, Swallow 1859), although effects of other interacting disturbances and drought also promote canopy openness (McEwan et al. 2011). Oak woodlands with these characteristics occurred throughout North America pre-EAS despite being relatively rare today (Hanberry et al. 2014). During the twentieth century to the present, rates of forest transitions from opento closed-canopy conditions have varied by region and species assemblages (Guyette et al. 
2003, DeSantis et al. 2011, Cocking et al. 2012, Stambaugh et al. 2014a). In long-unburned areas with minimal ground flora diversity, the seedbank often evidences relict woodland conditions through its diversity and the site requirements of seedbank species (Hutchinson et al. 2005, Waldrop et al. 2008, Kinkead et al. 2013).

For these reasons and others, fire is increasingly considered in silvicultural systems and ecological restoration (Albrecht and McCarthy 2006, Dey and Schweitzer 2014, Kabrick et al. 2014). Benefits of fire treatments and woodland conditions are diverse and arguably critical to sustaining the oak ecosystem, including enhancing oak regeneration (Arthur et al. 2012, Brose et al. 2013); increasing understory plant species cover and richness (Hutchinson et al. 2005, Ratajczak et al. 2012, McCord et al. 2014); and improving diversity of native insects (Wood et al. 2011), birds (Reidy et al. 2014), and mammals (McShea et al. 2007, Starbuck et al. 2015). At larger scales, other benefits of woodlands may be realized, such as improved wildlife diversity through increasing early-successional habitat (Thompson and DeGraff 2001), decreased hazardous fuel loads, and increased climate change resilience (Brandt et al. 2014).

Incorporating fire science into management faces many challenges, particularly in the eastern US. Overall, fire's role in science, land management, and society is poorly understood and not well-founded (Pyne 2007). Compared to other natural sciences (e.g., forestry, wildlife, hydrology, botany, atmospheric science), fire research and professional scholarship has lagged behind and has not been of primary interest, despite being a linking theme. In Eastern hardwood forests, challenges and varying perspectives exist related to incorporating fire into forest management (Packard 1993, Matlack 2013, Stambaugh et al. 2015). A primary point of contention is that promoting fire use, particularly in hardwoods, can be perceived as inherently in conflict with other forest management objectives (i.e., fire prevention, wood fiber production, and human health promotion; Weldon 1996).

Historical fire regimes of eastern US oak woodlands vary at spatial scales from landscapes to regions (Guyette et al. 2003, 2006; Stambaugh et al. 2014b). Through time, historical fire intervals within Eastern oak woodlands can vary by an order of magnitude within the spatial extent of study sites (e.g., $1 \mathrm{~km}^{2}$ ). When managing for woodland conditions with fire, it is not clear whether maintenance of woodland structures should focus on temporal or spatial variability in fire (or some combination). Understanding the historical distribution of woodlands, how fire regimes varied across landscapes, and how vegetation responded to fire regime departures would benefit understanding their successional pathways and designing management systems. Fire disturbance properties are often simplified by disregarding variability in metrics and how they change with scale (Falk et al. 2007). To characterize the temporal variability in fire regimes and to describe the spatial dependence of fire intervals, we analyzed eight multi-century fire scar records from two historically post oak (Quercus stellata Wangenh.)-dominated woodland landscapes. The objectives of this study were to: 1) reconstruct and contrast historical fire regime characteristics of sites within two different landscapes using fire scar analysis and, 2) quantify the effect of spatial scale of observation on fire frequency. With this information, we discuss the implications for historical data interpretation and oak woodland fire management. We expect that further understanding scaling theory of fire regimes will inform fire management decisions such as planning and employing burn treatments with characteristics (e.g., frequency, size, location, severity, patchiness) that historical fires once produced. 


\section{METHODS}

\section{Study Landscape and Site Descriptions}

Study landscapes consisted of the Wichita Mountains Wildlife Refuge (WMWR) in the Cross Timbers region of southwest Oklahoma, USA, and Arnold Air Force Base (AAFB) in The Barrens region of south-central Tennessee, USA (Figure 1, Table 1). These landscapes are approximately $1150 \mathrm{~km}$ apart with contrasting physical, climatological, and biological properties (Figure 1). At each landscape, fire scar history data were collected from four sites across an approximately 100 $\mathrm{km}^{2}$ area historically dominated by post oak woodlands. Data from the WMWR were collected from 2006 to 2011 and are reported in Stambaugh et al. $(2009,2014 a)$, while data from AAFB were collected from 2004 to 2005 and are reported here.
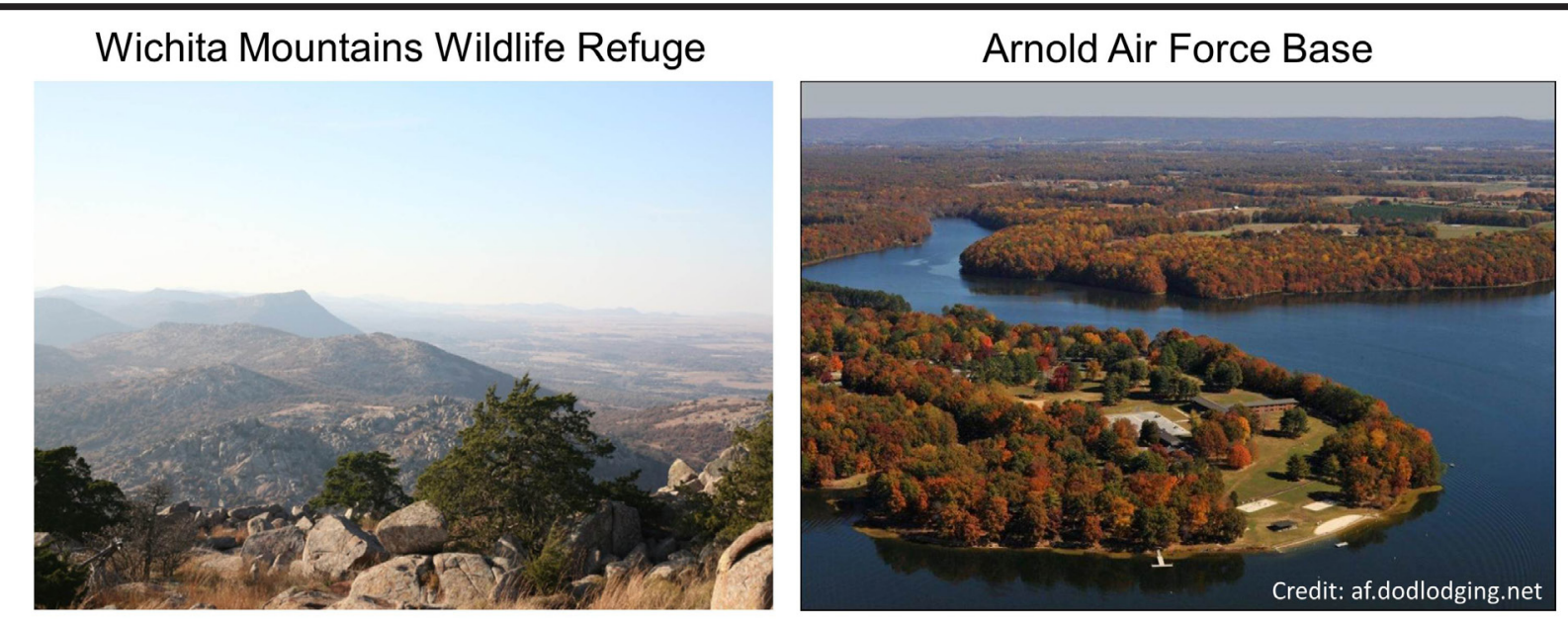

Figure 1. Study landscapes at the Wichita Mountains Wildlife Refuge, Oklahoma, USA, and Arnold Air Force Base, The Barrens, Tennessee, USA.

Table 1. Characteristics of the Wichita Mountains and The Barrens study landscapes.

\begin{tabular}{lll}
\hline & Wichita Mountains, Oklahoma & The Barrens, Tennessee \\
\hline Ownership & US Fish and Wildlife Service & Arnold Air Force Base \\
Location & $34^{\circ} 45^{\prime} 29^{\prime \prime} \mathrm{N}, 98^{\circ} 42^{\prime} 21^{\prime \prime} \mathrm{W}$ & $35^{\circ} 22^{\prime} 16^{\prime \prime} \mathrm{N}, 86^{\circ} 5^{\prime} 18^{\prime \prime} \mathrm{W}$ \\
Terrain & mountainous $(310 \mathrm{~m}$ elevation) & flat to rolling (43 m elevation) \\
Temperature min./max. & $9.7^{\circ} \mathrm{C}$ to $23.8^{\circ} \mathrm{C}^{\mathrm{a}}$ & $8.6^{\circ} \mathrm{C}$ to $21.1^{\circ} \mathrm{C}^{\mathrm{b}}$ \\
\hline Annual precipitation & $78 \mathrm{~cm}^{\mathrm{a}}$ & $142 \mathrm{~cm}^{\mathrm{b}}$ \\
\hline Land types & woodlands, grasslands, rock outcrops & forested uplands, wetlands \\
Substrate & rhyolite, cobbly & limestone \\
Climate & semi-arid and humid continental & humid continental \\
Surrounded by & Osage Plains & Nashville Basin and Highland Rim \\
\hline
\end{tabular}

a Annual mean from 1912 to 2012.

${ }^{\mathrm{b}}$ Annual mean from 1893 to 2004. 


\section{Dendrochronology and Fire Scar History}

At both landscapes, four study sites (0.3 $\mathrm{km}^{2}$ to $1 \mathrm{~km}^{2}$ ) were established following methods described in Stambaugh et al. (2014a). Within the boundary of AAFB, fire scar history sites were established at Huckleberry Ridge (HCK), Rowland Creek Headwaters (RCH), Saltwell Hollow (SLT), and Lemm Swamp (LEM) (Figure 2). Site data from WMWR are reported in Stambaugh et al. $(2014 a)$. Sites were selected non-randomly based on the availability of mature, fire- scarred post oaks and were spatially distributed to maximize distance between sites and incorporate variation in landscape characteristics. Trees at each site were evaluated for sampling adequacy based on bole soundness, evidence of basal wounding, external tree condition and architecture, and visual inspection of basal cross-sectional surfaces. Attempts were made to sample a range of tree sizes, ages, and growth rates throughout the full period (more than 250 years; Guyette and Stambaugh 2004). Cross sections (10 $\mathrm{cm}$ to $30 \mathrm{~cm}$ thick) were cut from the base of post oak trees

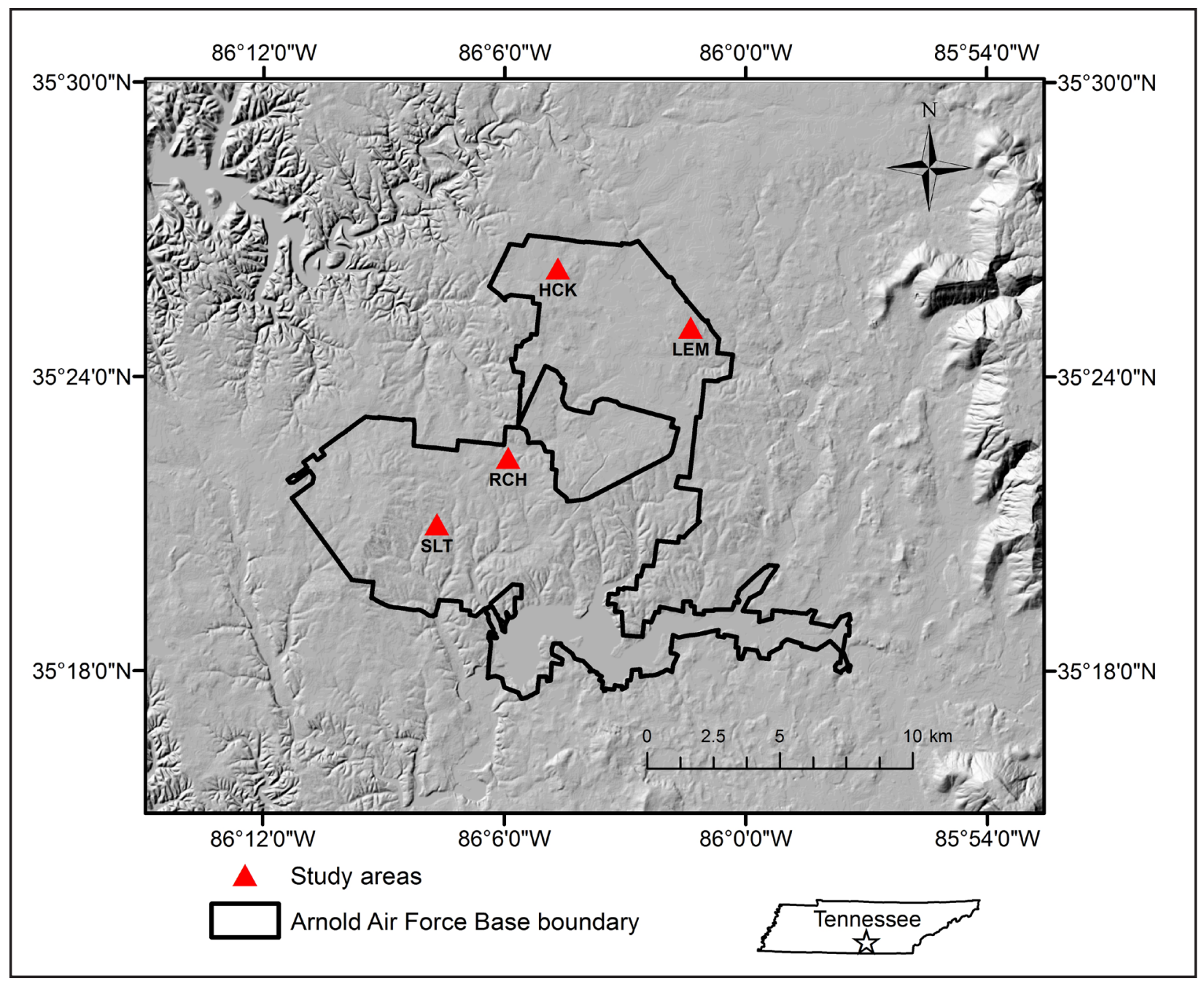

Figure 2. Hillshaded digital elevation model of landscape of Arnold Air Force Base (AAFB) and vicinity. Locations of study areas are represented by triangles with site codes $(\mathrm{HCK}=$ Huckleberry Ridge, $\mathrm{RCH}=$ Rowland Creek Headwaters, SLT $=$ Saltwell Hollow, LEM $=$ Lemm Swamp). Star symbol within inset map of Tennessee indicates the location of AAFB. 
using a chainsaw. Cross sections were assigned a sample number, orientation, slope direction, and geographic location.

For each study site, fire scar history records consisted of 30 to 50 trees, $>100$ fire scars, and spanned 250 years or more. Fire scars on post oaks were dated using standard dendrochronological techniques (Stokes and Smiley 1968) utilizing master ring-width chronologies developed at the study areas (NOAA 2008; M. Stambaugh, University of Missouri, Columbia, Missouri, USA, unpublished data). Fire scars were dated to the year of cambial response to injury and, if during the growing season, to a within-ring location following methods described by Kaye and Swetnam (1999). Fire scars were identified by the presence of charcoal, callus tissue, and bark fissure scar patterns (Guyette and Stambaugh 2004). Composite fire scar chronologies were constructed by compiling fire scar data for individual study sites.

\section{Data Analyses}

Summary statistics for fire scars and intervals were calculated using FHAES and FHX software (Grissino-Mayer 2001). Fire intervals were defined as the number of years between two consecutive fire events. Mean fire intervals (MFIs) represented the average fire interval length in years. Median fire intervals (i.e., median intervals) were reported when the distribution of fire intervals fit the Weibull distribution. For AAFB, summary statistics were derived for four time periods associated with cultural changes: pre-EAS (pre-1834), Euro-American settlement (1834 to 1926), military ownership (post-1926), and the full period of record. The pre-EAS period at AAFB was defined as pre-1834 based on the timing of the Removal Act of 1830, when Native Americans were forced westward from the region (i.e., area containing study sites) with many groups ultimately residing in Oklahoma. Summary statistics of fire scar data at the WMWR are published in Stambaugh et al. (2014a) and reproduced here. At WMWR, time periods were defined as: pre-EAS (i.e., pre-Fort Sill, 1850), conflict (with Native Americans) and Euro-American settlement (1850 to 1901), public ownership (post-1901), and the full period of record (Stambaugh et al. 2014a).

For individual study sites $(n=8)$, fire intervals were derived from the composite fire scar chronologies (i.e., record of fires at the site based on all scars on all trees) and represented the occurrence of fire somewhere in the study site. We calculated summary statistics for fire intervals, percentages of trees scarred, and fire scar seasonality. Percentages of trees scarred were calculated by year then averaged across all years to generate a mean per site. Statistics were calculated separately for the different time periods of interest. For cases in which fire intervals spanned more than one period, intervals were assigned to the period with the majority of the interval years. Percentages of trees scarred were calculated for years in which at least four trees were represented in the record.

To describe the relationship between spatial scale of observation and MFIs, we compiled pre-EAS fire intervals at three spatial scales: individual trees $\left(\sim 1 \mathrm{~m}^{2}, n=194\right.$ fire intervals), study sites $\left(\sim 1 \mathrm{~km}^{2}, n=152\right.$ fire intervals), and landscapes $\left(\sim 100 \mathrm{~km}^{2}, n=93\right.$ fire intervals). We calculated MFIs at the tree, site, and landscape scale for data from AAFB and WMWR separately. In addition, we calculated MFIs across these scales for all data compiled across both oak woodland study regions. Ranges and frequency distributions were plotted at each of these scales. Based on the work of Falk et al. (2007) that demonstrated fire frequency followed power-law behavior over space, we chose to represent the relationship between MFI and spatial scale with a negative-exponential model fit using SigmaPlot v12.3 software (SYSTAT Software, San Jose, California, USA). The presentation of the model is simply to demonstrate the relation- 
ship between MFI and spatial scale, not to provide prediction, since only three spatial scales were considered.

\section{RESULTS}

\section{Fire History at AAFB, The Barrens, Tennessee}

A total of 143 trees were sampled across the four fire history sites at AAFB (Table 2, Figure 3). The maximum and minimum time period spanned by sites was 1631 to 2004 (374 yr) and 1727 to 2004 (278 yr), respectively. A total of 423 fire scars and 205 fire intervals were identified from the four study sites (Table 2). When site data were pooled (i.e., landscape scale), 138 fire intervals were identified. All sites spanned a common period of 1727 to 2003. When sites were considered separately, composite fire intervals ranged from 1 yr to 35 yr, but when considering the entire landscape, composite fire intervals ranged from 1 yr to 26 yr. For the full period of record for each site, MFIs ranged from $2.9 \mathrm{yr}$ to $6.5 \mathrm{yr}$. At decadal scales, sites shared some similar patterns in fire frequency through time including increased fire events in the few decades prior to 1800, decreased fire from about 1830 to 1850 , and decreased fire in the latter half of the twentieth century (Figure 3). The MFIs among sites ranged from $3.3 \mathrm{yr}$ to $5.2 \mathrm{yr}$ pre-1834, to $2.5 \mathrm{yr}$ to $10.3 \mathrm{yr}$ from 1824 to 1926 , to $5.7 \mathrm{yr}$ to $10.3 \mathrm{yr}$ post-1926. The trend of longer site MFIs during the pre-EAS period, to shortened MFIs following EAS, to longer MFIs in the latter twentieth century was shared by sites at both AAFB and WMWR (Tables 1 and 2). Annual burning (i.e., two fire years in sequence) occurred at all sites; however, at Lemm Swamp, this only occurred once while all other sites had at minimum 10 cases. The longest fire-free period occurred at HCK site from 1936 to 2003, a $67 \mathrm{yr}$ period (Table 2, Figure 3).

Low severity fires (defined as $\leq 10 \%$ trees scarred in a fire event) were the most common across all sites. Overall, percentages of trees scarred at sites ranged from $2 \%$ to $60 \%$, the same range as at WMWR (Table 3). Also similar between the landscapes, the percentages of trees scarred at each site trended downward between pre-EAS and settlement periods, but generally trended upward from settlement to current day (Tables 1 and 2, Figure 3). Based on tree ages, no evidence of complete stand-replacing fires occurred at any sites within AAFB or the WMWR during the period of record. Fire seasonality was dominated by dormant season fires. Both $\mathrm{HCK}$ and $\mathrm{RCH}$ sites had exclusively dormant season fires. Growing season scars constituted $3 \%$ at both the SLT and LEM sites.

\section{Contrasting Fire Regimes between Tennessee and Oklahoma}

Many similarities existed between the historical fire regimes in Tennessee and Oklahoma (Tables 1 and 2, Figure 4). Sites spanned similar time periods, likely due to presence of post oak reaching maximum longevity. At sites in both landscapes, fire events during the pre-EAS period were generally less frequent, with slightly higher average percentages of trees scarred compared to the following $\mathrm{Eu}-$ ro-American settlement period. For the full period of record, fires were more frequent at sites $\left(1 \mathrm{~km}^{2}\right)$ in Tennessee than in Oklahoma, but at the landscape scale $\left(100 \mathrm{~km}^{2}\right)$, they were similar $(\mathrm{MFI}=2.2$ years at AAFB versus 2.6 years at WMWR). Both landscapes had primarily dormant season fires with slightly greater numbers of growing season fires in Oklahoma (although seasonality was undeterminable for many scars). Ranges of percentages of trees scarred were widest in the preEAS period for both landscapes (Tables 1 and 2). Similarly, mean percentages of trees scarred decreased in the settlement era when overall burning frequency increased among sites. 
Table 2. Fire scar history data at the site and landscape scale for Arnold Air Force Base. Data are stratified by time periods associated with cultural changes. Data for fire intervals on individual trees are not shown in this table but can be viewed in Figures 3 and 5 .

\begin{tabular}{lccccc}
\hline & $\begin{array}{c}\text { Huckleberry } \\
\text { Ridge }\end{array}$ & $\begin{array}{c}\text { Rowland Creek } \\
\text { Headwaters }\end{array}$ & Saltwell Hollow Lemm Swamp & All sites \\
\hline Spatial extent $\left(\mathrm{km}^{2}\right)$ & $\sim 1$ & $\sim 1$ & $\sim 1$ & $\sim 1$ & $\sim 100$ \\
All years & & & & & \\
\hline Time period & 1721 to 2003 & 1727 to 2003 & 1631 to 2004 & 1701 to 2004 & 1631 to 2004 \\
Trees $(n)$ & 34 & 44 & 35 & 30 & 143 \\
Fire intervals $(n)$ & 58 & 58 & 54 & 35 & 138 \\
Mean fire interval (yr) & 2.9 & 4.52 & 5.7 & 6.5 & 2.23 \\
Fire interval range (yr) & 1 to 13 & 1 to 35 & 1 to 28 & 1 to 32 & 1 to 26 \\
Median interval (yr) & 2.4 & 3.2 & 3.9 & 5.2 & na \\
Mean trees scarred (\%) & 9.4 & 8.9 & 16.1 & 11.6 & $38.4^{\text {a }}$ \\
Range trees scarred (\%) & 3 to 39 & 2 to 40 & 3 to 60 & 3 to 38 & 25 to $100^{\text {a }}$ \\
Fire scars $(n)$ & 112 & 135 & 117 & 59 & 423 \\
Dormant season fires (\%) & 100 & 100 & 96 & 98 & 98 \\
Growing season fires (\%) & 0 & 0 & 4 & 2 & 2 \\
Undetermined (\%) & 0 & 0 & 0 & 0 & 0
\end{tabular}

Prior to Euro-American settlement period (before 1834)

$\begin{array}{lccccc}\text { Time period } & 1721 \text { to } 1834 & 1727 \text { to } 1834 & 1631 \text { to } 1834 & 1701 \text { to } 1834 & 1631 \text { to } 1834 \\ \text { Trees }(n) & 22 & 25 & 18 & 17 & 82 \\ \text { Fire intervals }(n) & 20 & 24 & 31 & 22 & 60 \\ \text { Mean fire interval (yr) } & 3.3 & 3.92 & 4.45 & 5.18 & 2.33 \\ \text { Fire interval range (yr) } & 1 \text { to } 10 & 1 \text { to } 35 & 1 \text { to } 28 & 1 \text { to } 16 & 1 \text { to } 24 \\ \text { Median interval (yr) } & 2.93 & 2.48 & 3.1 & 4.29 & 1.64 \\ \text { Mean trees scarred (\%) } & 13.6 & 10.3 & 21.3 & 14.9 & 43.3^{\text {a }} \\ \text { Range trees scarred (\%) } & 5 \text { to } 29 & 4 \text { to } 30 & 6 \text { to } 60 & 6 \text { to } 38 & 25 \text { to } 100^{\text {a }} \\ \text { Fire scars }(n) & 33 & 38 & 62 & 36 & 169 \\ \text { Dormant season fires (\%) } & 100 & 100 & 97 & 97 & 97 \\ \text { Growing season fires (\%) } & 0 & 0 & 3 & 3 & 3 \\ \text { Undetermined }(\%) & 0 & 0 & 0 & 0 & 0\end{array}$

Euro-American settlement period (1834 to 1926)

$\begin{array}{lccccc}\text { Time period } & 1834 \text { to } 1926 & 1834 \text { to } 1926 & 1834 \text { to } 1926 & 1834 \text { to } 1926 & 1834 \text { to } 1926 \\ \text { Trees }(n) & 33 & 36 & 26 & 30 & 125 \\ \text { Fire intervals }(n) & 36 & 25 & 10 & 8 & 60 \\ \text { Mean fire interval (yr) } & 2.53 & 3.24 & 8.4 & 10.25 & 1.52 \\ \text { Fire interval range (yr) } & 1 \text { to } 13 & 1 \text { to } 8 & 2 \text { to } 23 & 3 \text { to } 32 & 1 \text { to } 4 \\ \text { Median interval (yr) } & 1.95 & \text { na } & \text { na } & \text { na } & 1.43 \\ \text { Mean trees scarred (\%) } & 7.28 & 6.07 & 9.45 & 7.44 & 34.17 \text { a } \\ \text { Range trees scarred (\%) } & 3 \text { to } 39 & 3 \text { to } 23 & 4 \text { to } 19 & 3 \text { to } 12 & 25 \text { to } 75^{\text {a }} \\ \text { Fire scars }(n) & 74 & 53 & 23 & 17 & 167 \\ \text { Dormant season fires (\%) } & 99 & 100 & 100 & 100 & 100 \\ \text { Growing season fires }(\%) & 1 & 0 & 0 & 0 & 0 \\ \text { Undetermined }(\%) & 0 & 0 & 0 & 0 & 0\end{array}$

Military use (1926 to 2004)

\begin{tabular}{lccccc}
\hline Time period & 1926 to 2003 & 1926 to 2003 & 1926 to 2004 & 1926 to 2004 & 1926 to 2004 \\
Trees $(n)$ & 34 & 44 & 34 & 30 & 142 \\
Fire intervals $(n)$ & 1 & 7 & 11 & 3 & 17 \\
Mean fire interval (yr) & na & 10.29 & 6.55 & 5.67 & 4.35 \\
Fire interval range (yr) & na & 2 to 32 & 1 to 26 & 1 to 11 & 1 to 26 \\
Median interval (yr) & na & na & 4.25 & na & 2.7 \\
Mean trees scarred $(\%)$ & 7.5 & 14.71 & 8.5 & 5 & $36.11^{\text {a }}$ \\
Range trees scarred (\%) & 6 to 9 & 2 to 40 & 3 to 18 & 3 to 7 & 25 to $75^{\text {a }}$ \\
Fire scars $(n)$ & 5 & 44 & 32 & 6 & 87 \\
Dormant season fires $(\%)$ & 100 & 100 & 91 & 100 & 92 \\
Growing season fires $(\%)$ & 0 & 0 & 9 & 0 & 8 \\
Undetermined $(\%)$ & 0 & 0 & 0 & 0 & 0 \\
\hline
\end{tabular}

${ }^{a}$ based on percentages of sites scarred. 


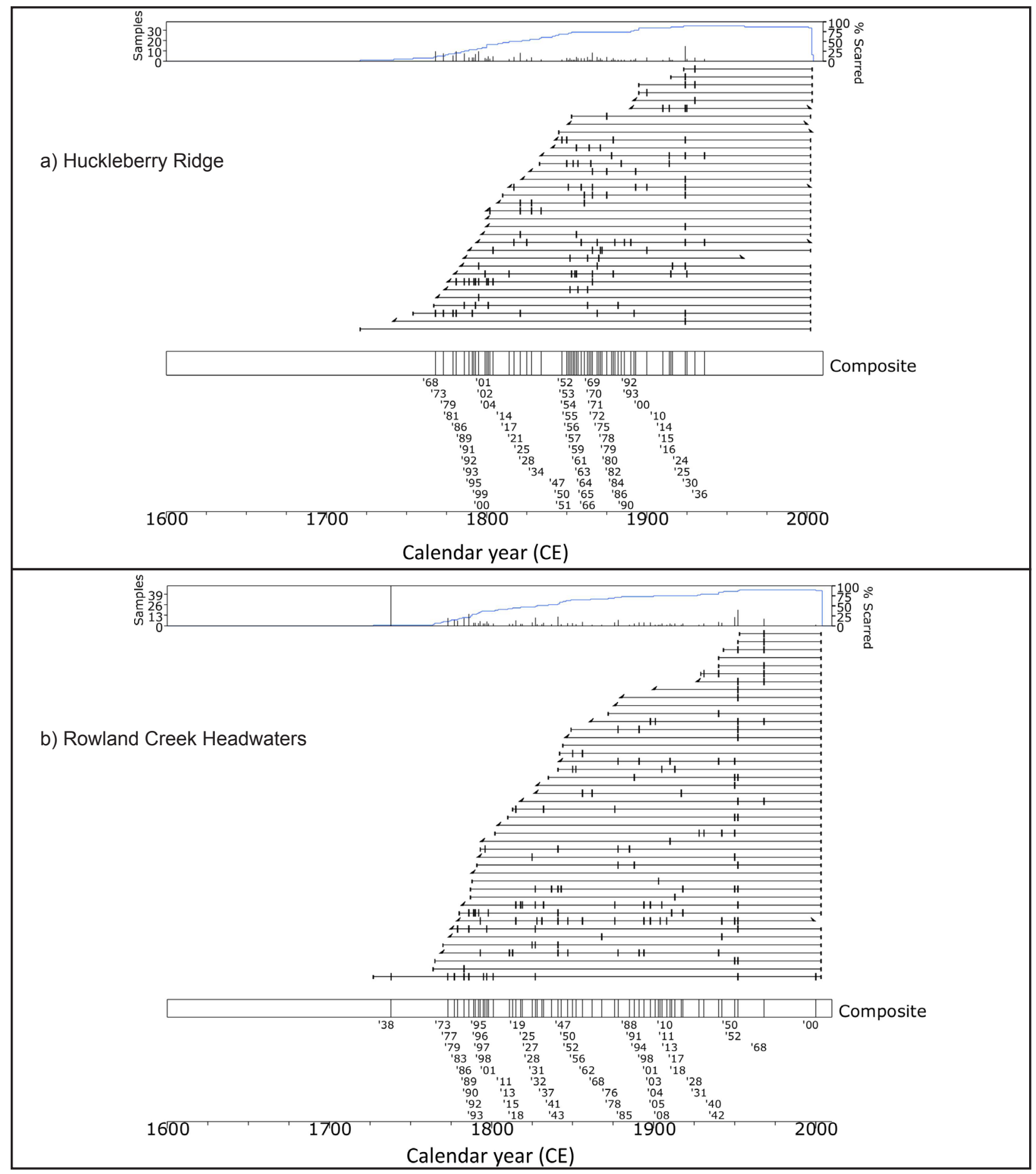

Figures 3a and 3b. Post oak fire scar history charts of two of the four individual study sites at Arnold Air Force Base in The Barrens region of Tennessee, USA. On study site charts, top boxes indicate numbers of trees recording (blue line) and percentages of trees scarred (vertical bars) through time. Below, horizontal lines represent the periods of tree-ring record for individual trees. Bold vertical ticks on horizontal lines indicate fire scar years. On the left ends of lines, vertical ends indicate pith years while diagonal ends indicate inner ring year (rings missing to center). On the right ends of lines, vertical ends indicate bark years while diagonal ends indicate outer ring years (rings missing to bark). A composite of all fire years at the site is given at the bottom of charts. 


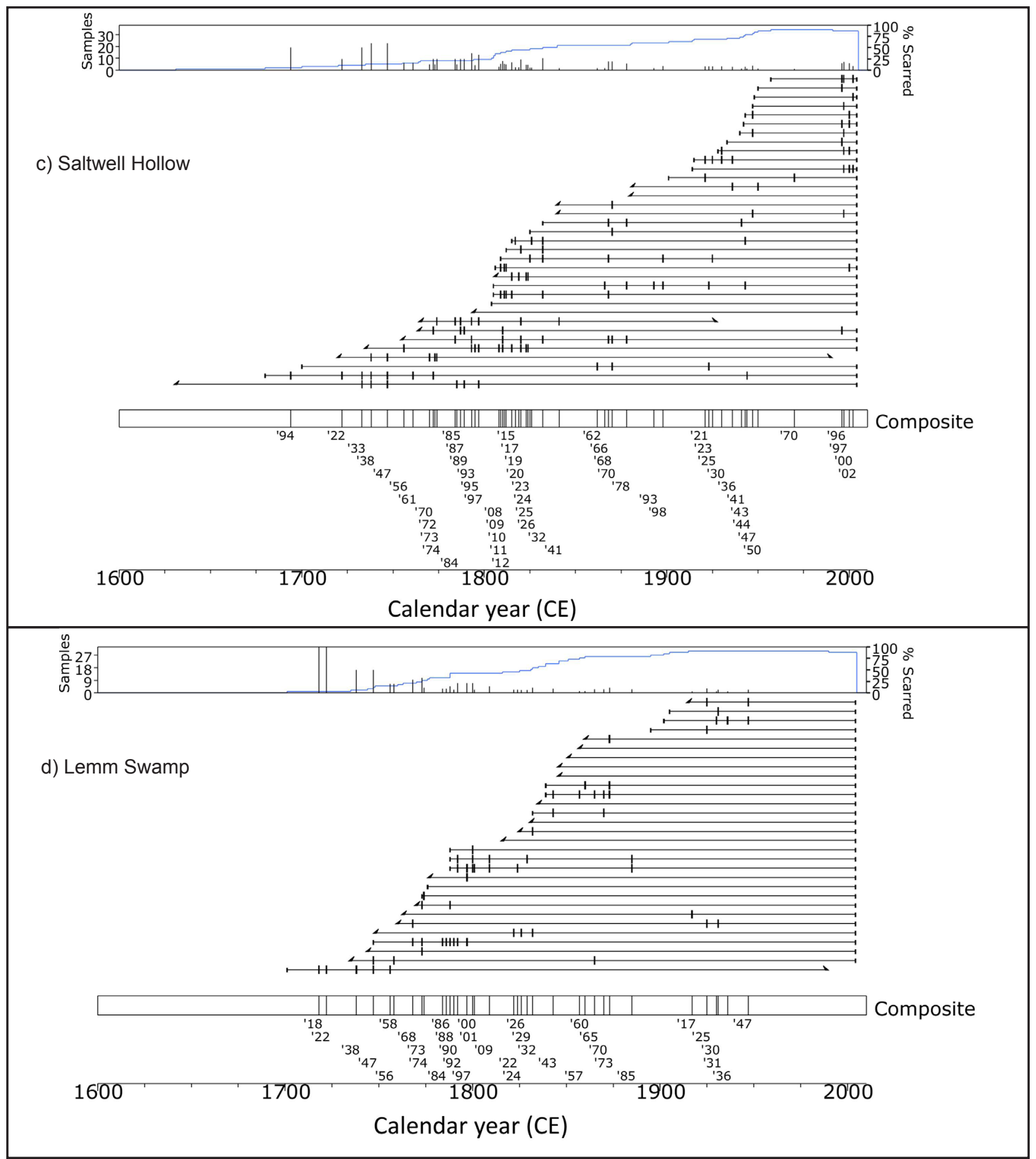

Figures 3c and 3d. Post oak fire scar history charts of two of the four individual study sites at Arnold Air Force Base in The Barrens region of Tennessee, USA. On study site charts, top boxes indicate numbers of trees recording (blue line) and percentages of trees scarred (vertical bars) through time. Below, horizontal lines represent the periods of tree-ring record for individual trees. Bold vertical ticks on horizontal lines indicate fire scar years. On the left ends of lines, vertical ends indicate pith years while diagonal ends indicate inner ring year (rings missing to center). On the right ends of lines, vertical ends indicate bark years while diagonal ends indicate outer ring years (rings missing to bark). A composite of all fire years at the site is given at the bottom of charts. 
Table 3. Fire scar history data at the site and landscape scale for the Wichita Mountains. Data are stratified by time periods associated with cultural changes. Data for fire intervals on individual trees are not shown in this table, but can be viewed in Figure 5 or Stambaugh et al. 2014a.

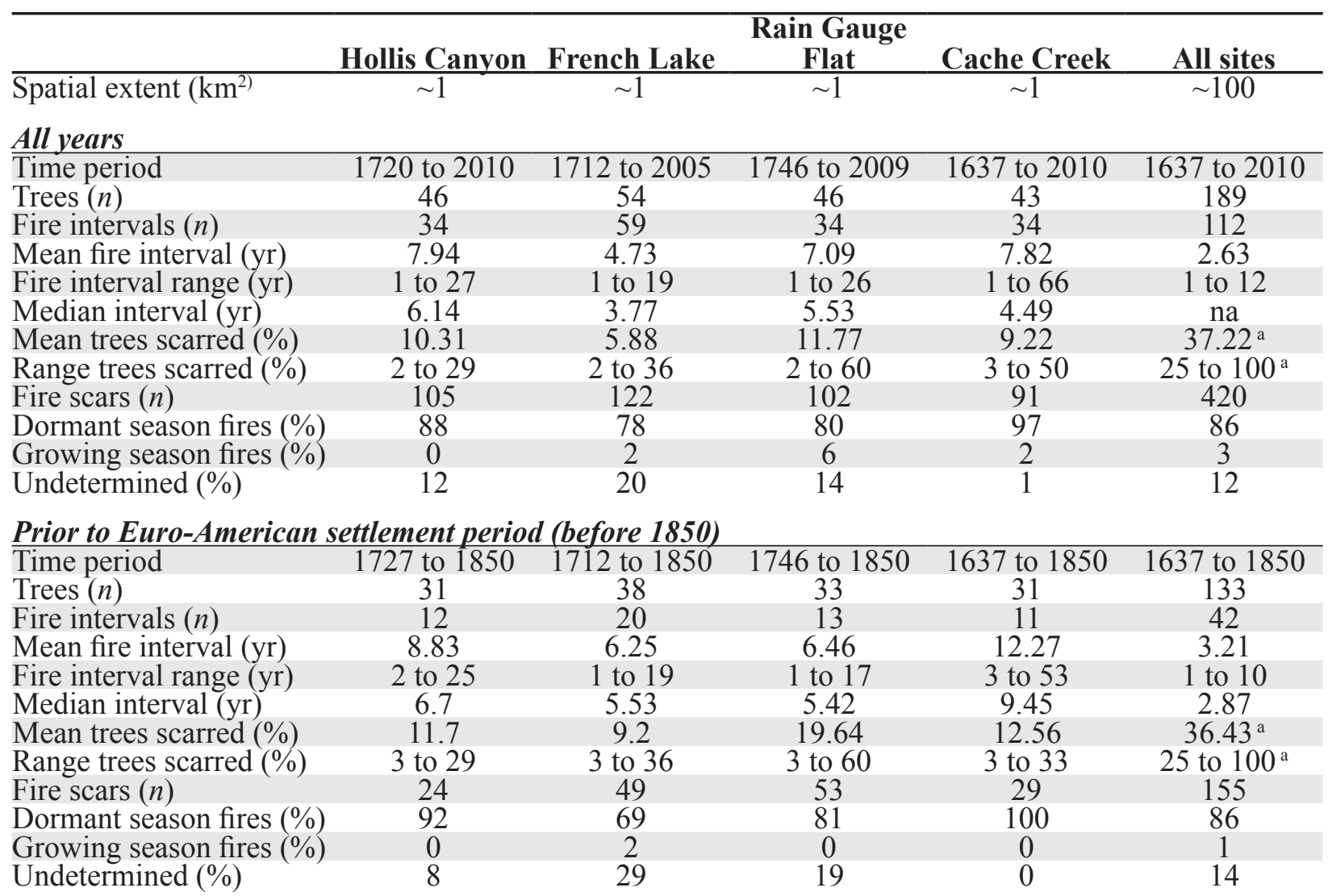

Conflict and settlement period (1850 to 1901)

\begin{tabular}{lccccc} 
Time period & 1850 to 1901 & 1850 to 1901 & 1850 to 1901 & 1850 to 1901 & 1850 to 1901 \\
Trees $(n)$ & 46 & 53 & 34 & 36 & 169 \\
Fire intervals $(n)$ & 11 & 19 & 13 & 18 & 38 \\
Mean fire interval (yr) & 3.55 & 2.42 & 3.23 & 2.72 & 1.29 \\
Fire interval range (yr) & 1 to 8 & 1 to 7 & 1 to 8 & 1 to 7 & 1 to 3 \\
Median interval (yr) & 3.35 & na & 2.99 & 2.42 & na \\
Mean trees scarred (\%) & 8.58 & 4.65 & 5.23 & 7.26 & $41.67^{\text {a }}$ \\
Range trees scarred (\%) & 3 to 19 & 2 to 10 & 3 to 12 & 3 to 32 & 25 to $100^{\text {a }}$ \\
Fire scars $(n)$ & 33 & 38 & 26 & 45 & 142 \\
Dormant season fires (\%) & 85 & 84 & 77 & 93 & 85 \\
Growing season fires (\%) & 0 & 3 & 15 & 4 & 6 \\
Undetermined (\%) & 15 & 13 & 8 & 2 & 10 \\
Public ownership (1901 to & $\mathbf{2 0 1 0}$ & & & & \\
Time period & 1901 to 2010 & 1901 to 2005 & 1901 to 2009 & 1901 to 2010 & 1901 to 2010 \\
Trees (n) & 46 & 54 & 46 & 43 & 189 \\
Fire intervals $(n)$ & 9 & 18 & 6 & 4 & 31 \\
Mean fire interval (yr) & 10.67 & 5.22 & 16.67 & 19.25 & 3.42 \\
Fire interval range (yr) & 1 to 27 & 1 to 19 & 7 to 26 & 2 to 66 & 1 to 12 \\
Median interval (yr) & 8.85 & 4.04 & 16.33 & 8.70 & 2.89 \\
Mean trees scarred (\%) & 11 & 3.68 & 9 & 10.4 & $32.28^{\text {a }}$ \\
Range trees scarred (\%) & 2 to 11 & 2 to 10 & 2 to 23 & 3 to 17 & 25 to $75^{\text {a }}$ \\
Fire scars $(n)$ & 52 & 35 & 23 & 20 & 130 \\
Dormant season fires (\%) & 88 & 83 & 83 & 95 & 87 \\
Growing season fires (\%) & 0 & 3 & 9 & 5 & 4 \\
Undetermined (\%) & 12 & 14 & 9 & 0 & 9 \\
\hline
\end{tabular}

a based on percentages of sites scarred. 


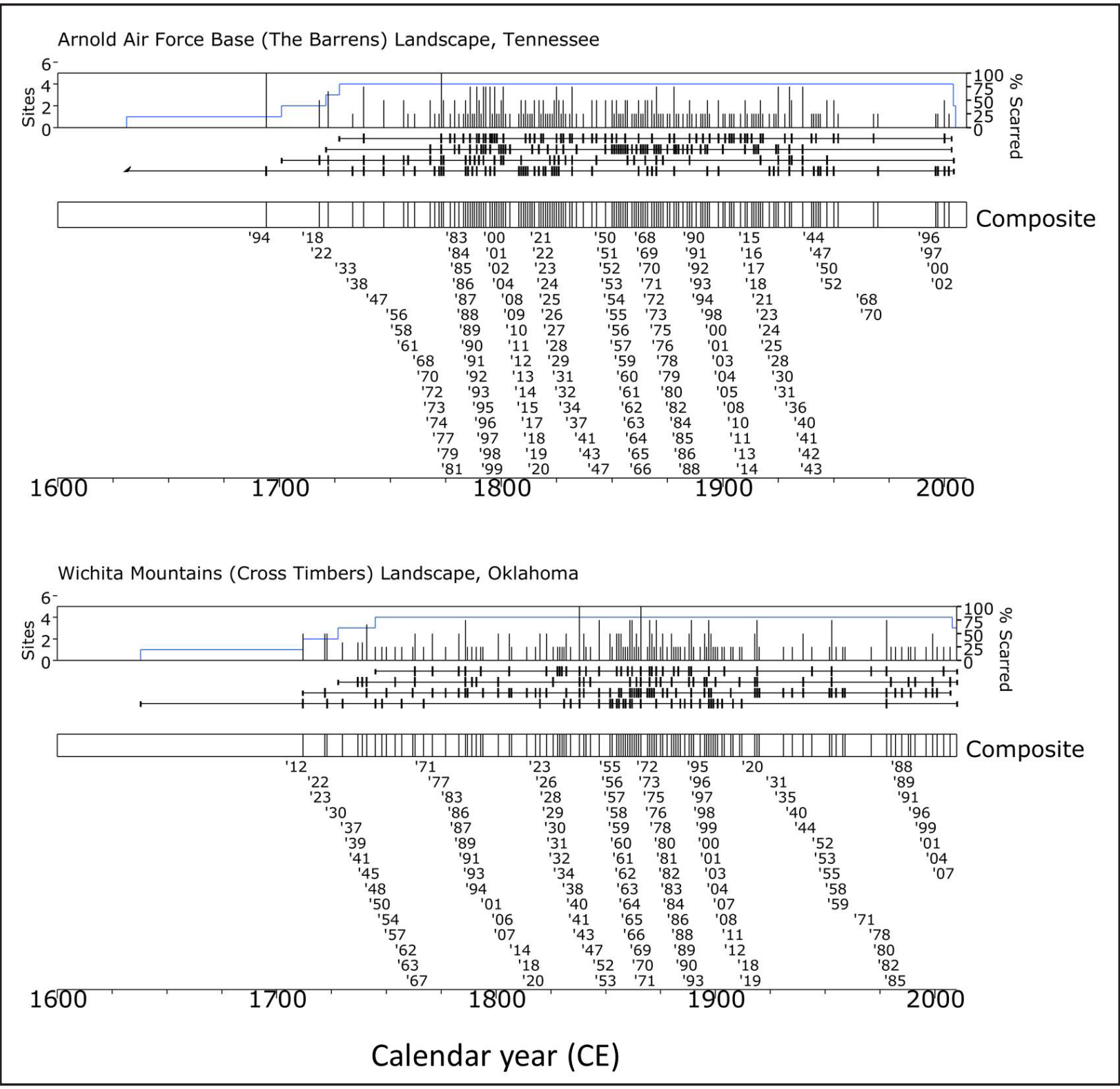

Figure 4. Fire scar history diagrams for Arnold Air Force Base and Wichita Mountains post oak woodland landscapes (areas of approximately $100 \mathrm{~km}^{2}$ ). Top boxes indicate number of sites recording (blue line) and percentages of sites scarred (vertical bars) through time. Below, horizontal lines represent the periods of record of each site (i.e., each horizontal line represents all trees combined from sites shown in Figure 3). Fire scar dates at the bottom of this chart represent the occurrence of fire events within the landscape extent $\left(\sim 100 \mathrm{~km}^{2}\right)$.

\section{Spatial Scale Dependence of Pre-EAS MFIs}

Pre-EAS fire intervals decreased from the spatial extent of individual trees $\left(1 \mathrm{~m}^{2}\right)$, to sites $\left(1 \mathrm{~km}^{2}\right)$, to landscapes $\left(100 \mathrm{~km}^{2}\right)$ (Figure 5). Fire intervals on individual trees ranged from $1 \mathrm{yr}$ to $38 \mathrm{yr}$ at AAFB, and $1 \mathrm{yr}$ to $90 \mathrm{yr}$ at WMWR. Mean fire intervals on individual trees were $8.7 \mathrm{yr}$ at AAFB and $19.8 \mathrm{yr}$ at WMWR. At the site scale, fire intervals ranged from $1 \mathrm{yr}$ to $35 \mathrm{yr}($ mean $=4.3)$ at AAFB, and $1 \mathrm{yr}$ to $53 \mathrm{yr}($ mean $=8.0)$ at WMWR. At the landscape scale, fire intervals ranged from $1 \mathrm{yr}$ to $24 \mathrm{yr}($ mean $=2.3)$ at 

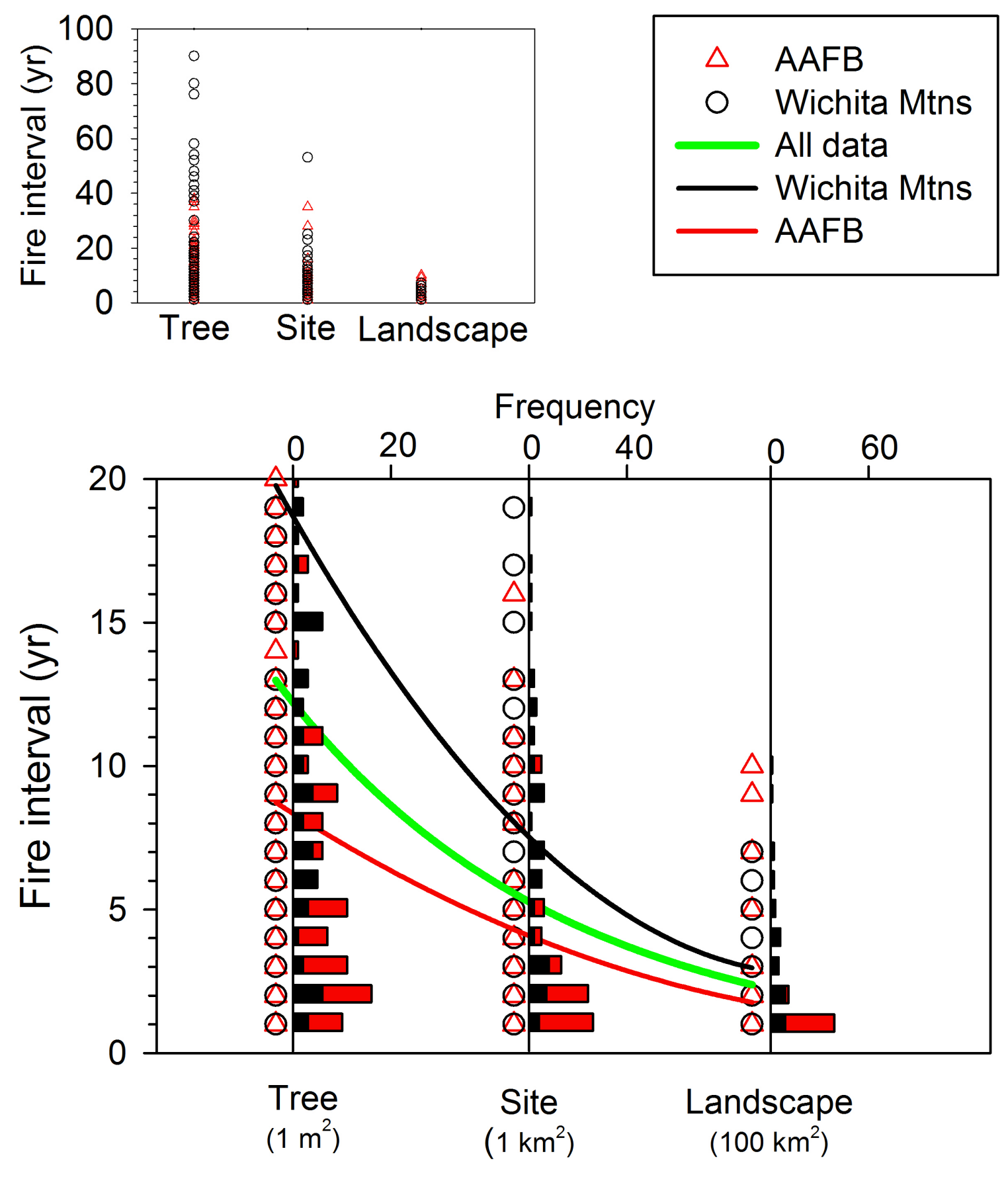

Spatial scale

Figure 5. Pre-EAS period fire intervals at the scales of individual tree, site, and landscape. Fire intervals are separated by site indicated by triangle and circle symbols (see graph at top left for full range of observed intervals). Horizontal bars represent the frequency of observations for each interval. Curves depict the negative exponential relationship between mean fire interval (MFI) and scale. The MFIs at each spatial scale were fit with a negative exponential curve. Separate curve fits are shown for data from all oak woodland sites and the two study landscapes separately. 
$\mathrm{AAFB}$, and $1 \mathrm{yr}$ to $10 \mathrm{yr}($ mean $=3.2)$ at WMWR. The negative exponential equation relating pre-EAS period mean fire interval to spatial extent was given as:

$$
M F I=12.96 \times e^{(-0.82 \times \text { area })},
$$

where $\mathrm{MFI}=$ mean fire interval at the respective spatial extent, area is in $\mathrm{km}^{2}$ (Figure 5).

\section{DISCUSSION}

Fire scars on trees are spatially explicit data, which can be an advantage over other historical sources such as documentary records. For example, personal observations like Swallow's (1859) commonly cited description of annually occurring fires in Missouri oak woodlands rarely include a spatial reference. Based on our results, annually occurring fires were limited (maximum of 10 times over a three-century period at the study site extent) and would not be the MFI of post oak woodlands, unless considering landscape fire occurrence rates for areas $>3 \mathrm{~km}^{2}$ (based on Equation 1 and on fire data from four sites per landscape). Other evidence, such as experimental burn studies, also suggests that long-term frequent ( $<2 \mathrm{yr}$ ) to annual burning is too frequent to sustain tree recruitment in oak forest communities (Peterson and Reich 2001, Knapp et al. 2015). One explanation for how fires could have been reported to have historically burned annually while tree recruitment was sustained might be due to only portions of a given landscape burning in a single year when fire occurrence was reported.

Disturbances such as fire vary by spatial and temporal scales due to differences in influences of drivers and controls (Turner 1987). Understanding signatures in spatial and temporal dependence reveals clues to the type and relative importance of environmental controls. In the US, networks of historical fire scar data have shown how fire regime drivers and controls vary from tree to subcontinental scales, including their relevance to vegetation change, human populations and cultures, and climate conditions (Guyette et al. 2002, 2006; Taylor and Skinner 2003; Falk et al. 2011). In general, we found fire to be more frequent in Tennessee than in Oklahoma, particularly preEAS. This result is somewhat surprising considering that Tennessee sites are generally wetter, more humid, and not in a significantly more lightning-ignition prone region. Frequent fire regimes, particularly with the aforementioned conditions, are commonly attributed to anthropogenic influence (Guyette et al. 2002). McClain et al. (2010) found more frequent fires during a pre-EAS period in a post oak woodland in Illinois, USA (MFI = $1.97 \mathrm{yr}$ from 1776 to 1850), while Guyette et al. (2003) found less frequent fires in a southern Indiana, USA, woodland (MFI $=23 \mathrm{yr}$ from 1620 to 1820 ). Other studies exist from post oak woodlands in Oklahoma and Texas, USA, and these report pre-EAS MFIs between 3.3 yr to $6.7 \mathrm{yr}$ (Clark et al. 2007, DeSantis et al. 2010, Allen and Palmer 2011, Stambaugh et al. 2011)—values that fall within the range of data presented here. All of the post oak fire data mentioned above were derived from sites within the western and north-central portion of the range of post oak and, therefore, may not characterize conditions farther east and south with wetter and warmer climates, varied vegetation and fuels, and differing fire regime characteristics (i.e., fire seasonality, ignition sources).

Scale dependence of historical fire regimes could influence fire management planning, the interpretation of natural and documentary archival data, and models that simulate landscape fire disturbance (e.g., LANDIS; Wang et al. 2014). In this study, fire scar data were used to explore the scale dependence of fire intervals from tree to landscape scales. Results describing how fire intervals vary by extent are among the first reported in the eastern US; additional studies are needed to test these findings. Fire scar wounding measurements paired with fire behavior and burn area information would like- 
ly improve relationships and interpretation at each extent. One expected bias of our fire scar data is that the frequency of fire recorded at the individual tree scale was probably lower than actually occurred due the fact that individual trees may not record all fire events. In this case, the characterization of mean fire interval at the individual tree extent could be more frequent than our model (Equation 1) would suggest. Additional biases may affect our results, such as our inability to randomly select study site locations within landscapes.

\section{Relevance to Oak Woodland Ecology and Management}

Fire history data provide perspective, and possibly a basis, for oak forest community management in the eastern US. The value of fire history data is not only that they inform management, but also that they further understanding of scale effects, landscape fire heterogeneity, and long-term vegetation dynamics of active fire regimes. These data can span more than 300 years and identify processes that vary on time scales much longer than professionals' careers or experiments. This is particularly relevant to open oak canopy structures such as woodlands and savannas, within which fire disturbance may have been the most important factor responsible for their existence and conditions (Dey and Kabrick 2015), but for which little guidance exists within written documentation, living memory, or management experience.

For present day management of fire-dependent communities, it is important to remember that, historically, forest community structures and compositions encountered during EAS most likely did not previously undergo extensive cutting treatments, despite being the most common vegetation manipulation technique in restoration projects today. Further, historical fire conditions (i.e., severity, extent) were not bound by modern-day societal and physical barriers (e.g., safety, emissions, roads, chang- ing land uses), likely allowing for a greater potential for more extensive, longer duration, and higher severity fires to occur historically. Generally, in Eastern hardwood forests, the effects of cutting vegetation are not a surrogate for fire, particularly in regard to the ground-belowground impacts and thermal selection for smaller-sized, thin bark vegetation following low severity fires (Waldrop et al. 2008). Indeed, cutting treatments may be a necessary activity in woodland and savanna restoration to achieve the desired structure of trees due to the limited ability of low intensity fires to reduce the density of larger diameter trees (e.g., trees $>10 \mathrm{~cm} \mathrm{dbh),} \mathrm{almost} \mathrm{regardless} \mathrm{of} \mathrm{spe-}$ cies (Arthur et al. 2015). Bark thickness on larger diameter trees can be sufficient to protect the cambium from fire-girdling during low intensity fires even for what are considered fire-sensitive species (Hutchinson et al. 2005). Mechanical thinning of the overstory, in conjunction with prescribed burning, is commonly combined in initial restoration efforts until desired structure is achieved that can then be more easily maintained by a regime of prescribed burning (e.g., Hutchinson et al. 2005, Waldrop et al. 2008, Kinkead et al. 2013).

It is important to consider the spatial and temporal variation in historical fire regimes and how those resulted in the mosaic of prairie, savanna, woodland, and forest as fire interacted with topography and other site factors that influenced ignition potential and fire behavior. Heterogeneity in fire coverage and effects probably affected historical woodland conditions (i.e., presence or absence, tree density, and species). Prescribed fire to restore woodlands is commonly applied to hundreds to thousands of hectares at a time. Our results suggest that, within the extent of a landscape, great variability exists in fire frequency. Recognition and quantification of these disturbance properties could aid in understanding the ecology and management of fire-dependent natural communities. Within safety, social acceptance, and human resource limitations, fire 
treatments (e.g., ignitions, behavior) that are allowed to be influenced by environmental constraints (e.g., seasonality, terrain influences), promote mosaics of natural communities and fulfillment of the range of natural variation in composition and structure within a community type.

\section{ACKNOWLEDGEMENTS}

For work at AAFB, we thank G. Call and C. Strohmeier of ACS Conservation for their support, assistance in fieldwork, and providing previously collected data for the study site. We also thank CH2MHill, Arnold Air Force Base, E. Roworth, R. Short, and reviewers for their comments and guidance. At the Wichita Mountains Wildlife Refuge, we thank R. Godfrey and W. Munstermann for their assistance in locating study sites and conducting research. Fieldwork and laboratory assistance was provided by E. Abadir, A. Bale, P. Bennett, M. Bourscheidt, L. Graves, L. Hammer, C. Kinkead, and M. Kyd.

\section{LITERATURE CITED}

Albrecht, M.A., and B.C. McCarthy. 2006. Effects of prescribed fire and thinning on tree recruitment patterns in central hardwood forests. Forest Ecology and Management 226: 88103. doi: 10.1016/j.foreco.2005.12.061

Allen, M.S., and M.W. Palmer. 2011. Fire history of a prairie/forest boundary: more than 250 years of frequent fire in a North American tallgrass prairie. Journal of Vegetation Science 22: 436-444. doi: 10.1111/j.1654-1103.2011.01278.x

Arthur, M.A., H.D. Alexander, D.C. Dey, C.J. Schweitzer, and D.L. Loftis. 2012. Refining the oak-fire hypothesis for management of oak-dominated forests of the eastern United States. Journal of Forestry 110: 257-266. doi: 10.5849/jof.11-080

Arthur, M.A., B.A. Blankenship, A. Schörgendorfer, D.L. Loftis, and H.D. Alexander. 2015. Changes in stand structure and tree vigor with repeated prescribed fire in an Appalachian hardwood forest. Forest Ecology and Management 340: 46-61. doi: 10.1016/j.foreco.2014.12.025

Bailey, R.G. 1997. Ecoregions of North America. 1:15,000,000 scale map (rev.). USDA Forest Service, Washington, D.C., USA.

Brandt, L., H. He, L. Iverson, F.R. Thompson III, P. Butler, S. Handler, M. Janowiak, S.P. Danielle, C. Swanston, M. Albrecht, R. Blume-Weaver, P. Deizman, J. DePuy, W.D. Dijak, G. Dinkel, S. Fei, T.D. Jones-Farrand, M. Leahy, S. Matthews, P. Nelson, B. Oberle, J. Perez, M. Peters, A. Prasad, J.E. Schneiderman, J. Shuey, A.B. Smith, C. Studyvin, J.M. Tirpak, J.W. Walk, W.J. Weng, L.Watts, D. Weigel, and S. Westin. 2014. Central Hardwoods ecosystem vulnerability assessment and synthesis: a report from the Central Hardwoods Climate Change Response Framework project. USDA Forest Service General Technical Report NRS-124, Northern Research Station, Newtown Square, Pennsylvania, USA.

Braun, E.L. 1950. Deciduous forests of eastern North America. The Blakiston Company, Philadelphia, Pennsylvania, USA.

Brose, P.H. 2014. Development of prescribed fire as a sivicultural tool for the upland oak forests of the eastern United States. Journal of Forestry 112: 525-533. doi: 10.5849/jof.13-088

Brose, P.H., D.C. Dey, R.J. Phillips, and T.A. Waldrop. 2013. A meta-analysis of the fire-oak hypothesis: does prescribed burning promote oak reproduction in eastern North America? Forest Science 59: 322-334. doi: 10.5849/forsci.12-039 
Clark, S.L., S.W. Hallgren, D.M. Engle, and D.W. Stahle. 2007. The historic fire regime on the edge of the prairie: a case study from the Cross Timbers of Oklahoma. Proceedings of the Tall Timbers Fire Ecology Conference 23: 40-49.

Cocking, M.I., J.M. Varner, and R.L. Sherriff. 2012. California black oak responses to fire severity and native conifer encroachment in the Klamath Mountains. Forest Ecology and Management 270: 25-34. doi: 10.1016/j.foreco.2011.12.039

DeSantis, R.D., S.W. Hallgren, and D.W. Stahle. 2010. Historic fire regime of an upland oak forest in south-central North America. Fire Ecology 6(3): 45-61. doi: 10.4996/fireecology.0603045

DeSantis, R.D., S.W. Hallgren, and D.W. Stahle. 2011. Drought and fire suppression lead to rapid forest composition change in a forest-prairie ecotone. Forest Ecology and Management 261: 1833-1840. doi: 10.1016/j.foreco.2011.02.006

Dey, D.C., and J.M. Kabrick. 2015. Restoration of midwestern oak woodlands and savannas. Pages 401-428 in: J.A. Stanturf, editor. Restoration of boreal and temperate forests. Second edition. CRC Press, Boca Raton, Florida, USA.

Dey, D.C., and C.J. Schweitzer. 2014. Restoration for the future: endpoints, targets, and indicators of progress and success. Journal of Sustainable Forestry 33(sup1): S43-S65.

Dyer, J.M. 2001. Using witness trees to assess forest changes in southeastern Ohio. Canadian Journal of Forest Research 31: 1708-1718. doi: 10.1139/x01-111

Falk, D.A., E.K. Heyerdahl, P.M. Brown, C. Farris, P.Z. Fulé, D. McKenzie, T.W. Swetnam, A.H. Taylor, and M.L. Van Horne. 2011. Multi-scale controls of historical forest-fire regimes: new insights from fire-scar networks. Frontiers in Ecology and the Environment 9: 446-454. doi: $10.1890 / 100052$

Falk, D.A., C. Miller, D. McKenzie, and A.E. Black. 2007. Cross-scale analysis of fire regimes. Ecosystems 10: 809-823. doi: 10.1007/s10021-007-9070-7

Grissino-Mayer, H.D. 2001. FHX2-software for analyzing temporal and spatial patterns in fire regimes from tree rings. Tree-Ring Research 57: 115-124.

Guyette, R.P., D.C. Dey, and M.C. Stambaugh. 2003. Fire and human history of a barren-forest mosaic in southern Indiana. American Midland Naturalist 149: 21-34. doi: 10.1674/0003-0031(2003)149[0021:FAHHOA]2.0.CO;2

Guyette, R.P., D.C. Dey, M.C. Stambaugh, and R.M. Muzika. 2006. Fire scars reveal variability and dynamics of Eastern fire regimes. Pages 20-39 in: M.B. Dickinson, editor. Fire in Eastern oak forests: delivering science to land managers, proceedings of a conference. USDA Forest Service, General Technical Report NRS-P-1, Northern Research Station, Newtown Square, Pennsylvania, USA.

Guyette, R.P., R.M. Muzika, and D.C. Dey. 2002. Dynamics of an anthropogenic fire regime. Ecosystems 5: 472-486.

Guyette, R.P., and M.C. Stambaugh. 2004. Post oak fire scars as a function of diameter, growth, and tree age. Forest Ecology and Management 198: 183-192. doi: 10.1016/j.foreco.2004.04.016

Hanberry, B.B., J.M. Kabrick, and H.S. He. 2014. Densification and state transition across the Missouri Ozarks landscape. Ecosystems 17: 66-81. doi: 10.1007/s10021-013-9707-7

Hutchinson, T.F., R.E.J. Boerner, S. Sutherland, E.K. Sutherland, M. Ortt, and L.R. Iverson. 2005. Prescribed fire effects on the herbaceous layer of mixed-oak forests. Canadian Journal of Forest Research 35: 877-890. doi: 10.1139/x04-189 
Kabrick, J.M., D.C. Dey, C.O. Kinkead, B.O. Knapp, M. Leahy, M.G. Olson, M.C. Stambaugh, and A.P. Stevenson. 2014. Silvicultural considerations for managing fire-dependent oak woodland ecosystems. Pages 2-15 in: J.W. Groninger, E.J. Holzmueller, C.K. Nielsen, D.C. Dey, editors. Proceedings of the 19th Central Hardwood forest conference. USDA Forest Service General Technical Report NRS-P-142, Northern Research Station, Newtown Square, Pennsylvania, USA.

Kaye, M.W., and T.W. Swetnam. 1999. An assessment of fire, climate, and Apache history in the Sacramento Mountains, New Mexico. Physical Geography 20: 305-330.

Kinkead, C.O., J.M. Kabrick, M.C. Stambaugh, and K.W. Grabner. 2013. Changes to oak woodland stand structure and ground flora composition caused by thinning and burning. Pages 373-387 in: G.W. Miller, T.M. Schuler, K.W. Gottschalk, J.R. Brooks, S.T. Grushecky, B.D. Spong, and J.S. Rentch, editors. Proceedings of the 18th Central Hardwood forest conference. USDA Forest Service General Technical Report NRS-P-117, Northern Research Station, Newtown Square, Pennsylvania, USA.

Knapp, B.O., K. Stephan, and J.A. Hubbart. 2015. Structure and composition of an oak-hickory forest after over 60 years of repeated prescribed burning in Missouri, USA. Forest Ecology and Management 344: 95-109. doi: 10.1016/j.foreco.2015.02.009

Matlack, G.R. 2013. Reassessment of the use of fire as a management tool in deciduous forests of eastern North America. Conservation Biology 27: 916-926. doi: 10.1111/cobi.12121

McClain, W.E., T.L. Esker, B.R. Edgin, G. Spyreas, and J.E. Ebinger. 2010. Fire history of a post oak (Quercus stellata Wang.) woodland in Hamilton County, Illinois. Castanea 75: 461474. doi: 10.2179/09-007.1

McCord, J.M., C.A. Harper, and C.H. Greenberg. 2014. Brood cover and food resources for wild turkeys following silvicultural treatments in mature upland hardwoods. Wildlife Society Bulletin 38: 265-272. doi: 10.1002/wsb.403

McEwan, R.W., J.M. Dyer, and N. Pederson. 2011. Multiple interacting ecosystem drivers: toward an encompassing hypothesis of oak forest dynamics across eastern North America. Ecography 34: 244-256. doi: 10.1111/j.1600-0587.2010.06390.x

McShea, W.J., W.M. Healy, P. Devers, T. Fearer, F.H. Koch, D. Stauffer, and J. Waldon. 2007. Forestry matters: decline of oaks will impact wildlife in hardwood forests. Journal of Wildlife Management 71: 1717-1728. doi: 10.2193/2006-169

Nelson, P.W. 2005. The terrestrial natural communities of Missouri. Missouri Natural Areas Committee, Jefferson City, Missouri, USA.

NOAA [National Oceanic and Atmospheric Administration]. 2008. National Climatic Data Center. Stambaugh-French Lake-QUST-ITRDB OKO32. <https://www.ncdc.noaa.gov/cdo/ $\mathrm{f} ? \mathrm{p}=519: 1: 0:::: \mathrm{P} 1$ STUDY_ID:6174>. Accessed 21 March 2016.

Nowacki, G.J., and M.D. Abrams. 2008. The demise of fire and "mesophication" of forests in the eastern United States. Bioscience 58: 123-138. doi: 10.1641/B580207

Olmsted, F.L. 1857 [reprinted 1981]. A journey through Texas; or, a saddletrip on the southwestern frontier. Time-Life Books, Alexandria, Virginia, USA.

Packard, S. 1993. Restoring oak ecosystems: the savannas and woodlands of the Midwest are providing an arena for an emerging debate about the nature of these ecosystems - and of nature itself. Ecological Restoration 11: 5-16.

Peterson, D.W., and P.B. Reich. 2001. Prescribed fire in oak savanna: fire frequency effects on stand structure and dynamics. Ecological Applications 11: 914-927. doi: 10.1890/1051-0761(2001)011[0914:PFIOSF]2.0.CO;2 
Pyne, S.J. 2007. Problems, paradoxes, paradigms: triangulating fire research. International Journal of Wildland Fire 16: 271-276. doi: 10.1071/WF06041

Ratajczak, Z., J.B. Nippert, and S.L. Collins. 2012. Woody encroachment decreases diversity across North American grasslands and savannas. Ecology 93: 697-703. doi: 10.1890/11-1199.1

Reidy, J.L., F.R. Thompson, and S.W. Kendrick. 2014. Breeding bird response to habitat and landscape factors across a gradient of savanna, woodland, and forest in the Missouri Ozarks. Forest Ecology and Management 313: 34-46. doi: 10.1016/j.foreco.2013.10.042

Ryan, K.C., E.E. Knapp, and J.M. Varner. 2013. Prescribed fire in North American forests and woodlands: history, current practice, and challenges. Frontiers in Ecology and the Environment 11: e15-e24. doi: 10.1890/120329

Stambaugh, M.C., R.P. Guyette, R. Godfrey, E.R. McMurry, and J.M. Marschall. 2009. Fire, drought, and human history near the western terminus of the Cross Timbers, Wichita Mountains, Oklahoma. Fire Ecology 5(2): 51-65. doi: 10.4996/fireecology.0502051

Stambaugh, M.C., J.M. Marschall, and R.P. Guyette. 2014a. Linking fire history to successional changes of xeric oak woodlands. Forest Ecology and Management 320: 83-95. doi: 10.1016/j.foreco.2014.02.022

Stambaugh, M.C., J.C. Sparks, and E.R. Abadir. 2014b. Historical pyrogeography of Texas. Fire Ecology 10(3): 72-89. doi: 10.4996/fireecology.1003072

Stambaugh, M.C., J.C. Sparks, R.P. Guyette, and G. Willson. 2011. Fire history of a relict oak woodland in northeast Texas. Rangeland Ecology and Management 64: 419-423. doi: 10.2111/REM-D-10-00128.1

Stambaugh, M.C., J.M. Varner, R.F. Noss, D.C. Dey, N.L. Christensen, R.F. Baldwin, R.P. Guyette, B.B. Hanberry, C.A. Harper, S.G. Lindblom, and T.A. Waldrop. 2015. Clarifying the role of fire in the deciduous forests of eastern North America: reply to Matlack. Conservation Biology 29: 942-946. doi: 10.1111/cobi.12473

Starbuck, C.A., S.K. Amelon, and F.R. Thompson III. 2015. Relationships between bat occupancy and habitat and landscape structure along a savanna, woodland, forest gradient in the Missouri Ozarks. Wildlife Society Bulletin 39: 20-30. doi: 10.1002/wsb.512

Stokes, M.A., and T.L. Smiley. 1968. Introduction to tree-ring dating. University of Chicago Press, Illinois, USA.

Swallow, G.C. 1859. Geological report of the country along the line of the south-western branch of the Pacific Railroad, State of Missouri. George Knapp \& Company, St. Louis, Missouri, USA.

Taylor, A.H., and C.N. Skinner. 2003. Spatial patterns and controls on historical fire regimes and forest structure in the Klamath Mountains. Ecological Applications 13: 704-719. doi: 10.1890/1051-0761(2003)013[0704:SPACOH]2.0.CO;2

Thompson, F.R., III, and R.M. DeGraaf. 2001. Conservation approaches for woody, early successional communities in the eastern United States. Wildlife Society Bulletin 29: 483-494.

Turner, M.G. 1987. Landscape heterogeneity and disturbance. Springer-Verlag, New York, New York, USA. doi: 10.1007/978-1-4612-4742-5

Waldrop, T.A., D.A. Yaussy, R.J. Phillips, T.A. Hutchinson, L. Brudnak, and R.E.J. Boerner. 2008. Fuel reduction treatments affect stand structure of hardwood forests in western North Carolina and southern Ohio. Forest Ecology and Management 255: 3117-3129. doi: 10.1016/j.foreco.2007.11.010

Wang, W.J., H.S. He, J.S. Fraser, F.R. Thompson III, S.R. Shifley, and M.A. Spetich. 2014. LANDIS PRO: a landscape model that predicts forest composition and structure changes at regional scales. Ecography 37: 225-229. doi: 10.1111/j.1600-0587.2013.00495.x 
Weldon, L.A.C. 1996. Dealing with public concerns in restoring fire to the forest. Pages 56-58 in: C.C. Hardy and S.F. Arno, editors. The use of fire in forest restoration. USDA Forest Service General Technical Report INT-GTR-341, Intermountain Research Station, Ogden, Utah, USA.

Wood, E.M., A.M. Pidgeon, C. Gratton, and T.T. Wilder. 2011. Effects of oak barrens habitat management for Karner blue butterfly (Lycaeides samuelis) on the avian community. Biological Conservation 144: 3117-3126. doi: 10.1016/j.biocon.2011.10.010 